\title{
Towards the Compatibility of Professional and Scientific Learning Outcomes: Insights and Options in the Context of Competence Orientation
}

\author{
Volker Rein* \\ Federal Institute for Vocational Education and Training (BIBB), Department of Professional \\ Learning and Teaching, Robert-Schuman-Platz 3, 53175 Bonn, Germany
}

Received: 11.10.2017; Accepted: 28.11.2017; Published: 21.12.2017

\begin{abstract}
The steady increase in science-related requirements in operational areas of skilled and managing workforce is influencing worldwide the discourse on shaping professionalization. This article focuses on the compatibility of professional and scientific competence-oriented learning outcomes of qualification programmes within and across the education and training sectors. It is assumed that there is not, per se, a conceptual dichotomy in designing education and training programmes and credentials in a competence-oriented manner to address complex professional and scientific requirements in education and training in a compatible way.

The article tries to shift the discussion from a systemic and institutional focus to a conceptual- and requirement-oriented perspective on qualification design. Using Germany as an example, it discusses the conceptual intersections of Vocational Education and Training and academic Higher Education on competence, and comparatively analyzes competence-oriented instruments for the classification and the transparency of learning outcomes and their application in the education practice of dual study programmes with vocational reference qualifications. On this basis, the article elucidates identified characteristics of comprehensive professional-scientific competences and relevant requirement areas in education and training. In addition, further prerequisites for an integrated competence acquisition in education programmes are discussed as well. It is assumed that these characteristics can also be regarded as important prerequisites for the connectivity of qualifications and permeable pathways within and between education systems.
\end{abstract}

${ }^{*}$ Corresponding author: Rein@bibb.de

ISSN: $2197-8646$

http://www.ijrvet.net 
Keywords: VET, Vocational Education and Training, Competence, Professional and Scientific Learning Outcomes, Vocational and Academic Education

\section{The Framing Developments and Problems in Education and Training}

Education and qualifications in all variations is incrementally designed along knowledgeintensive requirements of lifelong learning, the labour markets and other societal areas in the industrialized countries (Raffe, 2003). Knowledge-based jobs in the main occupational areas of manufacturing as well as primary and secondary service areas are increasing globally (Euler \& Severing, 2014). The ongoing trend toward higher qualification of skilled workers and managers drives the discussion as to which extent occupational professionalization can be designed along academic requirements (Wolf, 2010; Rein, 2002). Of interest are programmes and credentials in education and training sectors which address professional and scientific requirements and competences in curricula, didactics and assessment.

Consequently, in European Higher Education (EU, 1999) consecutively organized study programmes are increasingly developed along parameters which also address professional requirements beyond academia. Professional competence has been defined as the qualification objective for academic degree programmes as well. At the same time, advanced vocational qualification programmes, such as those found in the German dual system, are under discussion to be systematically redesigned compatible to science-based parameters (Nida-Rümelin, 2014). Hybrid qualifications like associate programmes in Anglo-Saxon countries and dual bachelor programmes in Germany are regarded as qualification types which potentially generate curricula and assessments that address both academic and occupational requirements in an integrated way (BLK, 2008; Räbiger, 2007). These developments have significantly extended the intersection of education and training objectives (Breuer, 2005).

To promote transparency, comparability and quality of qualifications and the permeability of education pathways, the stakeholders of all education and training sectors in the European Union (EU) have agreed since the late 1990s to design education and training programmes based on competences and learning outcomes. The Europe-wide induced competence-oriented shift to learning outcomes (EU, 1999; 2002; 2004) has qualitatively upgraded the ongoing national discourse on permeable education systems and pathways in Germany (Wolter, 2010; Deutscher Bildungsrat, 1970).

Further essential political, legal and instrumental framing conditions have supported this development since then. Amendments to federal state higher education acts have contributed to competence-oriented permeability of education pathways at the interface between vocational and academic education (KMK, 2002; 2009). Starting in 2006 the Federal Ministry of Education and Research (BMBF, 2006) carried out the ANKOMProgramme on the development of instruments and methods for the recognition of professional competences within academic study programmes. Furthermore, the Ministry programme "Open University" promoted the link between Vocational Education and 
Training (VET) and academic Higher Education (HE) qualifications as well (BMBF, 2011). Finally, EU education ministers agreed on the competence-oriented European Qualifications Framework (EQF; EU, 2008) across all education sectors, which should promote the transparency between VET qualifications and academic HE qualifications as well as the permeability between both education sectors. Germany followed with the development and the implementation of a national qualifications framework for lifelong learning to achieve the same objectives (BMBF, KMK, \& AK DQR, 2011).

However, common criteria for learning-outcome-oriented curricula and assessment requirements which are compatible between VET and academic HE have not up to now been developed. Consequently, a German national education report demanded a crossover educational concept which would reduce dysfunctional competition between the education sectors (BMBF \& KMK, 2014). Facing their differences, especially with regard to the concept of qualification, both VET and academic Higher Education have to tackle the challenge to apply the compatible potential of the competence reference in the design of "their" qualifications. This is required by the education policy objectives of lifelong learning and permeability, as well as by the requirements of the labour market and other societal areas.

\section{The Research Approach}

This article begins the analysis of the compatibility of professional and scientific learning outcomes by discussing the conceptual differences and intersections of the comprehension of competence in both education sectors. It is evident that, in contrast to VET, academic HE programmes are systematically developed based on research-generated disciplinary knowledge and methodologies. However, it is assumed that there is not per se a conceptual dichotomy between the two education sectors to design education and training programmes and credentials along both professional and scientific requirements in a compatible way. Furthermore, it is asserted there is an implicit common competenceoriented potential to perform and to apply learning outcomes in specific learning or work contexts to solve complex problems.

From a predominantly pedagogical-epistemological perspective on the ongoing convergence developments concerning professional and academic knowledge and practice orientation in education and training (Harwood, 2010; Bailey \& Matsuzuka, 2003), this article elucidates the results of a comparative analysis of selected appropriate theoretical and instrumental approaches of competence. They have been developed and implemented for the classification, the transparency and the conceptualization of learning outcomes in both education sectors. In addition, it summarizes implementation experiences in qualification programmes at the intersection of VET and academic HE, focusing on dual study programmes referring to relevant VET qualifications.

On this basis, common characteristics of relevant learning and skill requirements and competences needed in education and training are identified which can be classified as both professional and scientific. This points not only at a competence-cluster relevant for specific learning units but also at a professional-scientific synthesis relevant for the design 
of complete education programmes. Finally, the article reveals possible consequences and open questions concerning the identification of professional-scientific requirements and competences for a compatible development of learning outcomes in qualifications and programmes within VET and academic HE as well as at the intersection of both education sectors.

The research approach used and the findings presented have been generated under the research project "Permeability promoting aspects of the design of qualifications and programmes in terms of competence orientation at the interface of VET and academic HE" (DUQUA; Rein, 2015). This article is predominantly based on analytical findings of the research on theoretical and instrumental concepts. It is complemented by selected empirical findings on conceptual and implementation practices in selected dual study Bachelor and Master programmes and qualifications in Germany with references to VET qualifications. The research had been predominantly carried out at universities of applied sciences in the fields of business studies, informatics and occupational pedagogy. The complete empirical findings will be released in a separate publication.

Please note that in this article, the term Higher Education (or academic HE) relates to any qualifications and programmes which has been developed based on academic disciplines and methodologies provided by comprehensive universities or by universities of applied sciences. This clarification is necessary as in education research and policy the term Higher Education sometimes includes non-academic programme provisions on higher levels (CEDEFOP, 2012). Similarly the use of the term Vocational Education and Training (VET) in this article refers, in the German context, to the dominant dual part of initial and advanced VET. The findings discussed are regarded as relevant for other VET formats as well.

Stressing the comprehensive approach of this article the terms occupational, professional, scientific and practice are not used exclusively in the context of specific education (sub-)systems, labour markets and other societal environments. They are understood here in a cross-over conceptual perspective to describe learning and skill requirements and relevant competence-oriented learning outcomes in education and training. Many jobs outside institutional academia require academic capabilities to accomplish occupational problems and tasks. And many vocational learning results can be recognized and applied in the academic context (Markowitsch, 2004).

The definition of the terms learning outcomes and qualification follow sector-overarching qualifications frameworks for lifelong learning. Learning outcomes "describe what learners know, understand and are able and ready to do on completion of a learning process" (German Qualifications Framework; BMBF, KMK, \& AK DQR, 2011, p. 17). The term qualification is understood as "a formal outcome of an assessment and validation process which is obtained when a competent body determines that an individual has achieved learning outcomes to given standards" (EU, 2008, p.11). This definition in the EQF does not follow the traditional, comprehensive understanding of qualification in the education and training of German-speaking countries, which includes the entirety of all competences relevant for specific occupational requirements (Breuer, 2005). 


\section{Conceptual Differences and Intersections between VET and Academic HE}

Between VET and academic HE some conceptual differences in the design of qualifications and programmes have had to be taken into account in terms of compatibility up to now. VET is directed at the demand for occupational middle skills and management workforce, whereas academic HE traditionally focusses on scientific enabling as well as on graduate and post graduate career pathways (Teichler, 2003). Likewise, universities have predominantly provided discipline-specific and knowledge-based competence achievement, while VET focuses on an action-oriented capability to perform in functions, tasks and processes. Academic curricula are designed along disciplinary systematics whereas VET programmes follow occupational performance requirements. The analysis of subject-specific knowledge, science-related application of methods and learning competence is promoted more systematically in academia than in a VET setting.

Both education sectors articulate in different ways the comprehension of competence and practice as central reference points for curricula and assessments. Academic education emphasizes proficiency in the sense of a potential to carry out required actions whereas VET focuses on performance-oriented competence as the major objective. In Germany, the occupation- and business-oriented pedagogic disciplines have focused their $R \& D$ activities predominantly on competence-related aspects within the initial and advanced VET of skilled workers, e.g., master craftsmen, and certified supervisors and specialists (Arnold \& Lipsmeier, 2006; Sloane, Twardy, \& Buschfeld, 2004). Following the agreements of the Bologna process for European HE, academic pedagogy has started R\&D work to promote the design of competence-oriented academic degree programmes above the current qualification objective acquisition of scientific competence (Pletl \& Schindler, 2007, p. 35; Brenner \& Niehs, 2008). However up to now, a homogeneous cross-over theoretical approach has not been established to discuss a compatible competence-oriented design of qualifications and programmes at the intersection of VET and academic HE. Research in the relevant pedagogy disciplines is still in the initial phase in this respect.

One of the most important starting points for a cross-education-sector approach is the intersection of action orientation ("Handlungsorientierung") in the education objectives of both VET and HE. All stakeholders in science, practice and policy in education have agreed on one educational objective: the acquisition of complete competence to act (Sloane, Twardy, \& Buschfeld, 2004). In occupational pedagogy, competence is theoretically understood as the capability to perceive, to design and to transform a situation appropriately (Franke, 2005). Didactic concepts focus on the acquisition of competences in a reflective manner to support problem-solving and a practical solution for actions undertaken (Arnold \& Müller, 1993). Following the educational objective on complete occupational competence in German dual VET, training profiles and programmes are explicitly designed along occupational action areas, functions and processes. This is done based on legal regulations for initial and advanced dual VET at both the federal level and state levels (BMBF, 2005; KMK, 2007). In German dual VET complete occu- 
pational competence is described by technical, social and human competences, including methodological, communication and learning competences (KMK, 2007). The learning outcomes in occupational profiles are described in knowledge, skills and abilities. This follows a holistic understanding of competence, which includes societal participation and personal development (Weinert, 2001).

The Federal Higher Education Act of 1976 requires that German academic HE prepare its graduates to match occupational tasks beyond the academic context with scientific methodologies (BMBF, 1976). This has never been appropriately adapted in the design and the didactics of study programmes. However, academic graduates can be regarded as members of discipline-based communities of practice, who are professionally able to perform scientific knowledge and methodologies in both academic and in non-academic contexts. This is confirmed by the consistently high labour market acceptance of academics. (Markowitsch, 2004; IW, 2010)

Finally the Bologna Process for European Higher Education in 1999 prescribed the qualification objective acquisition of occupational competence in the design of academic degree programmes. As a result, the German Federal States (KMK, 2003, p. 4ff) followed this change of perspective by defining and implementing, in particular, Bachelor degrees as qualifications which prepare students for occupational requirements through the acquisition of relevant competences (Jahn, 2007; Böhle, 2010). A pertinent conceptual anchor in all disciplines within academic HE is the ability to apply scientific findings and methodologies in occupational tasks and situations (Kohler, 2004, p. 32).

The traditional differentiation between, on the one side, science as a cognitive complex and, on the other side, practice as the quintessence of an action-related context outside of academia, must be discussed critically within the context of the action-oriented acquisition of competence in academic HE. Wildt (2007) proposes an extended perception of the notion of practice and practice-oriented learning to appropriately address the employability objective for academic graduates. The cognitive complex of science needs to be interpreted in relation to practice both outside of and inside of academia. The potential to generate and acquire competence in academic practice must be made explicit, which both addresses academia-internal requirements and is transferable to an external practice in all societal sectors including the labour market. This extension of a holistic notion of competence is compatible with the qualification objective of VET.

In order to address this extended comprehension, Schaper (2012) proposes to define competence in science as the capability to act appropriately, responsibly and successfully in those requirement areas, which are characterized by high complexity, novelty, uncertainty and the need for high quality solutions. Competence should be performed on the basis of knowledge, skills, abilities, motivational orientation and ethical attitudes. In particular, this includes capabilities to apply scientific concepts to complex requirements e.g. at work as well as the generation and design of new, innovative concepts and problem solutions. Furthermore, this comprises the ability to use scientific knowledge, concepts and methods to reflect on and regulate one's own analytical and problem-solving actions. This means an "action-theoretical" comprehension of competence, which interprets science-specific activities as actions applicable to non-academic requirements as well. 
In both education sectors, generic competences are regarded as essential prerequisites for the acquisition of a holistic competence (Wild, 1997; Mertens, 1974). Generic competences are based on knowledge, abilities and attitudes, which are multifunctional and versatile across domains. They enable individuals to apply technical knowledge and capabilities to complex and difficult occupational situations in new and unknown situations (Schaper, 2012; Wildt, 2011). In VET, these capabilities are acquired as an integral part of occupational competence. They are embedded in qualification and occupation profiles via relevant learning objectives and outcomes (BMBF, 2005; KMK, 2007). They are highly recognized, especially in academic education, as a prerequisite for the ability to adapt to numerous occupational areas beyond one's own discipline. However, in many degree programmes they are not yet explicitly integrated in curricula and didactic approaches. Many university departments for didactic affairs are offering discipline-non-specific programmes with generic competences (Chur, 2012).

Summarizing the conceptual intersections of competence understanding and orientation in both education sectors discussed above, holistic approaches with a common core are dominating. Also a dichotomy of scientific versus professional requirements and competences cannot be concluded per se (Markowitsch, 2004; Rein, 2011).

\section{Instrumental Reference Approaches and Practices for Competence-Oriented Professional and Scientific Learning Outcomes}

For further considerations to operationalize comprehensive learning outcomes at the interface of VET and academic HE, the research analyzed appropriate and well established classification and transparency instruments to identify common characteristics for compatible competence oriented professional and scientific learning outcomes. They should implicitly or explicitly address comprehensive requirements and competences across the two education sectors. These selected instrumental approaches had been comparatively analyzed concerning the underlying competence concept, its dimensions and the advanced degrees of complexity of requirements and competences in education and training.

\subsection{Classifications of Learning Outcomes: Taxonomies}

For decades, many conceptual approaches have described stages of learning by using taxonomies. Taxonomies classify learning objectives, arranged hierarchically by theoretical criteria. A lower category is always a subcategory of the higher level category (Sitte, 2001). Activities based on human behavior potential can be described separately or in an integrated way based upon cognitive, affective and psychomotoric competence dimensions (Vygotsky, 1978). 
Bloom's Taxonomy and Subsequent Developments

The theoretical debate on the description and the progression of learning outcomes and many practical approaches has, up to now, been influenced by the Bloom taxonomy and its underlying concept. The first version (Bloom et al., 1956) categorised cognitive learning hierarchically from basic knowledge and comprehension to advanced, complex competences in terms of analysis, synthesis and evaluation of concepts and processes. In later versions, the taxonomy dimensions which were previously based on a more holistic comprehension of capability were extended by affective and psycho-motoric learning (Bloom et al., 1964). The classification in the affective domain ranges from receiving and responding to more complex competences in terms of valuing and structuring values. In the psycho-motor domain, classification starts with imitation, later moving to action structures and naturalization on more complex levels of learning.

Anderson and Krathwohl revised the cognitive domain of Bloom's taxonomy by verbalizing the nouns, e.g. knowledge was changed to remembering and comprehension to understanding, and placing creating (synthesis) above evaluating (evaluation) in the highest level of complexity of the cognitive learning dimension. In addition, the researchers divided the cognitive dimension of learning into the subcategories factual, conceptual, process and meta-cognitive knowledge (Anderson \& Krathwohl, 2001). Based on this revised taxonomy, researchers at Iowa State University later specified this extended twodimensional domain structure of learning objectives by verbalized descriptions (Heer, 2012).

The following two taxonomies with major influence in education and training also describe the dimensions of learning in an integrated way:

\section{Dreyfus Taxonomy}

The Dreyfus taxonomy (Dreyfus \& Dreyfus, 1986) describes the learner progression from novice to expert on five levels in an integrated way. For example, at the proficient level, learners are regarded as having a deeper understanding of problems, the ability to plan and to carry out actions holistically and being consistently able to achieve a high standard. Expert learners are described as having an authoritative, deep and holistic understanding. They are regarded as being able to deal with routine matters intuitively, to go beyond existing interpretations and consistently achieve excellence.

\section{SOLO Taxonomy}

Focusing on the depth and quality, understanding as the major integrated learning dimension is described by the SOLO taxonomy (Biggs \& Collis, 1982; Biggs, 2014) as an increase in the complexity of connections in the levels of competence. Understanding starts at an uni-structural level and progresses to the relational and the extended abstract levels. The relational level of understanding indicates orchestration between facts and theory, action and purpose. Understanding of several components is required, which are all integrated conceptually, and the learner can apply the concept to familiar problems and work situations. The relevant indicative verbs are compare, contrast, explain causes, integrate, analyse, relate and apply. On the highest level (extended abstract level), the learner is required to conceptualise beyond what has been dealt within the 
actual teaching and learning process. Additionally, he is expected to generalise to new areas. The relevant indicative verbs are theorise, generalise, hypothesise, reflect and generate.

In an education system-neutral way the discussed taxonomies describe learning stages in competence related learning dimensions and partially in a comprehensive manner. Therefore they are relevant for an integrated development of professional and scientific learning outcomes.

\subsection{Transparency of Learning Outcomes: Qualifications Frameworks}

Qualifications frameworks have been developed and implemented both in Germany and worldwide as instruments to promote the transparency of competence-oriented learning outcomes. At the same time, they are designed to promote the comparability and the permeability of education and career pathways. Qualifications frameworks are an essential instrumental part of an education policy induced Shift to Learning Outcomes in qualification programmes (ETF, 2009). Examples of frameworks for lifelong learning and for education sector-specific purpose are of particular interest in this article.

\section{German Qualifications Framework for Lifelong Learning (GQF-LLL)}

Based on the Maastricht declaration of the EU education ministers (EU, 2004), the German Qualifications Framework for Lifelong Learning (GQF-LLL; BMBF, KMK, \& AK DQR, 2011) had been developed as a national extension to the EQF (EU, 2008). The GQF-LLL enables, for the first time, a cross-sector referencing of qualifications based on an action-oriented definition of competence defined as "the ability and readiness of the individual to use knowledge skills and personal, social and methodological competences and to behave in a considered, individual and socially responsible manner" (BMBF, KMK, \& AK DQR, 2011, p. 16). The GQF-LLL defines the central category competence as a holistic capability to act which is relevant for both education sectors (ibid).

In its requirement structure, the GQF-LLL describes professional and personal competences on eight levels in the dimensions of knowledge and skills as well as in social competence and autonomy, whereas the EQF structure only focuses on responsibility and autonomy when describing competence. Knowledge is specified in terms of depth and breadth. Skills are described in the dimensions of instrumental, systemic and judgment. Social competence is specified in terms of team and leadership abilities. Finally, the competence dimension autonomy is defined related to responsibility, reflectivity and learning abilities. As an example of more complex levels, the GQF-LLL level 7 requires learners to "be in possession of competences for the planning, the processing and the evaluating of comprehensive technical tasks and problem sets and be in possession of competences for autonomous management of processes within subareas of a scientific subject or within a field of occupational activity. The structure of requirements is characterised by complexity and frequent changes" (ibid).

A comparative study on the relevance of taxonomies for German dual advanced VET concludes that the holistic competence approach and dimensions of the GQF-LLL and its taxonomic descriptions appropriately address the broad requirement and action scope 
of advanced dual VET qualifications. This concerns especially complex degrees of social interactions and responsibility (Prakopchyk et al., 2015, p.16).

German Qualifications Framework for Advanced VET (GQF-AVET)

In 2014, the German Qualifications Framework for advanced VET (GQF-AVET) was implemented to safeguard quality assurance and progression of qualifications within this VET sector and to promote the recognition of prior learning towards academic HE (BMBF, 2014). This competence-oriented framework explicitly refers to the advanced levels 5 to 7 of the comprehensive German Qualifications Framework for Lifelong Learning and its overarching description of requirements and competences of the levels. The level descriptors of this instrument focus predominantly on operational and strategic leading and management competences, which are required in more complex job functions. However, a differentiated description in the competence domains to specify its holistic approach of competence is missing. This would include, for example, a specified description of knowledge in terms of depth and breadth, which are required by management functions, to be compared with academic requirements and to be recognized in the academic HE context.

German Qualifications Framework for Academic HE (GQF-HE)

A German Qualifications Framework for Academic Qualifications (GQF-HE; KMK, 2005) has been developed on the basis of the agreements and standards of the BolognaProcess (EU, 1999) for the development of a European Higher Education Area (EHEA) with the degree formats Bachelor, Master and Doctorate. The underlying Tuning approach for academic HE had been established to support shaping and implementing study programmes of the consecutive cycles agreed to in the EHEA-framework. The competence-oriented conceptualizations had been specified in the so-called Dublin Descriptors (Bologna Working Group on Qualifications Frameworks, 2005; Tuning Project, 2006). In the Tuning approach, competences represent a dynamic combination of knowledge and understanding, as well as skills and abilities defined as instrumental, systemic and interpersonal competences (Gonzlez \& Wagenaar, 2009).

In the GQF-HE discipline non-specific descriptors describe the requirements and competences of the three degree levels in two major and five minor competence dimensions. Following the European Framework for academic degree programmes it describes competences in an action-oriented way in knowledge and understanding and in proficiency. Knowledge and understanding focus on the extension and deepening of discipline-specific knowledge as a prerequisite for the proficiency to generate and transfer knowledge based on instrumental, systemic and communicative competences. For instance on the Bachelor level, systemic competence including judgements is defined as "the ability to gather and interpret relevant data usually within their field of study, to deduce scientific profound judgements that include reflection on relevant social, scientific or ethical issues and to shape autonomously subsequent learning processes" (KMK, 2005, p. 2). Instrumental competence is described on this level as the ability to "apply their knowledge and understanding to their work or occupation, devising and sustaining arguments and solving problems" (ibid). These acquired competences address requirements in academic 
disciplines as well as in the non-academic practice and are likewise implicitly relevant to complex occupational requirements.

In a refined version (KMK, 2017), the GQF-HE specifies the dimensions of its competence model which explicitly refer to the GQF-LLL competence dimensions to promote its instrumental connectivity. Knowledge and understanding as well as application and generation of knowledge both refer to professional competence in the GQF-LLL. Communication and cooperation correspond to social competence, and academic self-concept \& professionalism refers to self-competence $\&$ autonomy in the GQF-LLL. The document recommends specifying the degree level desciptors in the competence dimensions by using established taxonomies namely taxonomy developments based on Bloom (1956; 1964) and Anderson and Krathwohl (2001).

As assumed, qualifications frameworks for lifelong learning like the GQF-LLL and the EQF provide the most consistent comprehensive approach for a competence-oriented operationalisation of learning outcomes at the interface of vocational and acadcemic education. Their instrumental development took into account established holistic, categorial and classificatory concepts discussed before to describe the outcome of learning. In addition, new sector-specific academic qualifications frameworks conceptually address competences required in non-academic environments like the Qualifications Framework for Business Engineering (FFBT, 2012).

\subsection{Practices of Competence Oriented Description of Learning Outcomes at the Interface of Academic and Non-Academic Requirements}

In the research project DUQUA (Rein, 2015) the theoretical-conceptual and instrumental reference approaches on the design of curricula and assessment requirements had been analyzed empirically in a complementary research on selected representative dual Bachelor and Master study programmes in Germany predominantly provided by universities of applied sciences. The research focused on programmes in business administration, informatics and occupational pedagogy with references to initial and advanced VET qualifications. In all of the study programmes learning outcomes were described in a competence-oriented manner. However, a homogenous systematic application of conceptual and classificatory approaches for a comprehensive operationalization of learning oucomes could not be identified. The curricula and the assessment assignments to describe learning outcomes took into account the required Tuning systematic for the EHEA complemented by the systematic of the GQF-LLL and and Bloom's taxonomy in revised versions of Anderson and Krathwohl (2001) and of Heer (2012). In a few cases, study programmes describe competence requirements refering to the programme systematic for the dual vocational schools in Germany (KMK, 2007) albeit not across all learning units and assessment assignments.

Diverging from the discipline-oriented study programme objectives, the occupation field-oriented design of learning outcomes often dominates. In almost all study programmes, requirements of VET reference qualifications were taken into account in the learning outcome developments, but predominantly in a complementary way and rarely 
in a synthesized manner. The limited subject compatibility between vocational and academic curricula has led to the design of professional-scientific learning outcomes on a limited extent in intitial dual study programmes integrating VET programmes. Academic competence is, in these cases, defined as methodological capability, that is, as solving tasks rather than as scientific comprehension and mastery of the disciplinary context on the whole. In the programmes analyzed, the more professional and application-oriented learning outcomes and the more academic-theoretically oriented learning outcomes are not predominantly designed in a level-congruent way. Generally, the learning outcomes in all programmes are by and large not designed in a balanced professional-scientific polyvalent manner. Fundamental discipline specific differences concerning an integrated professional-scientific design of learning outcomes could not be identified.

Regardless of the still unchallenged university autonomy to design study programmes (Zervakis, 2008), all experts interviewed demanded the development of guidelines and manuals for a comprehensive competence-oriented professional-scientific design of learning outcomes in both curricula and assessment assignments which addresses needs in both academic and non-academic environments.

\section{Common Characteristics of Professional-Scientific Requirements and Competences}

Comparing and analyzing the theoretical-conceptual and classificatory approaches of competence-oriented learning discussed in the preceding chapters, which are applied in both education sectors, essential intersections can be identified in the following requirement and competence areas: knowledge and understanding; learning, identification and solution of problems; reflectivity and judgment; self-organisation and planning; selection and application of methods, decision-making, responsibility and leadership; communication and transfer.

The following synthesis of professional-scientific competences described in comprehensive requirement areas in education and training in figure 1 as meta-descriptors of learning outcomes has been generated on this basis. It addresses higher degrees of requirement complexity and is described in a subject-, discipline- and qualification-neutral way. All requirement and competence areas are compatible with the domains and descriptors of the comprehensive GQF-LLL and the GQF-HE discussed above. The GQF-AVET covers these areas predominantly implicitly. However the description follows a constructivist approach (Dreyfus \& Dreyfus, 1986; Biggs, 2014) to address a comprehensive perspective compatible with a holistic understanding of competence. 


\section{Comprehensive Professional-Scientific Requirement Areas and Competences}

\section{- Knowledge and Understanding}

Competences for a systematic analysis to master and to critically understand a comprehensive, integrated, advanced and partially specialised knowledge, its foundations and beyond in a subject, a discipline, a working field and to contribute to their further development.

\section{- Learning}

Competences for a self-regulated and autonomous learning, including research oriented learning to contribute new knowledge to a subject or a subject area.

\section{- Identification and solution of problems}

Competences for the systematic identification and analysis of complex problems and tasks and the development and application of appropriate solutions and innovative concepts in complex and uncertain requirement contexts to achieve a higher standard.

\section{- Reflectivity and judgment}

Competences for an advanced reflectivity and judgement towards complex matters, problems and tasks as well as towards one's own actions based on relevant knowledge and on ethical attitudes as well.

\section{- Self organisation and planning}

Competences for self-organisation and autonomous planning of solutions of complex problems and tasks including an appropriate situational and long term processing.

\section{- Selection and application of methods}

Competences for mastery of a comprehensive range of methods and instruments as well as for their selection and application to process and to solve complex problems and tasks.

\section{- Decision-making, responsibility and leadership}

Competences for autonomous decision-making, responsibility and leadership and the definition of objectives in complex, changing and uncertain requirement contexts.

\section{- Communication and transfer}

Competences for communication and transfer of compatible knowledge and insights from learning, research and work in complex and uncertain requirement contexts by deploying appropriate skills.

Figure 1: Comprehensive Professional-Scientific Requirement Areas and Competences 
In this article, professional-scientific competences are described as part of characteristics for shaping a broad concept of competence acquisition in programmes and qualifications at the interface of academic and non-academic education. They are understood as a synthesis of capabilities, which have been predominantly acquired in qualifications separately provided by the education systems.

Definition of Professional-Scientific Competences

Professional-scientific competences can be defined both as potential and as performative capabilities to address requirements which are characterised by high complexity, uncertainty and novelty. They demand higher degrees of autonomy and quality to act appropriately and responsibly to solve complex problems and tasks on a higher standard. Taking into account scientific concepts as well, they include capabilities for a systematic analysis and reflection on complex problems, the application of their solutions in relevant environments, and the generation of innovative ideas and concepts. Professional-scientific competences are based on subject-related and generic knowledge and skills, and on ethical attitudes as well.

Figure 2: Definition of Professional-Scientific Competences

The definition in figure 2 considers the action-theoretical, subject-related and domainoverarching comprehension of competences in VET research and pedagogy as contextspecific performance potentials and capabilities to perceive, shape and transform situations and refer to science specific competences as well (Franke, 2005; Arnold \& Lipsmeier, 2006; Schaper, 2012, p. 22ff). They are described in a level-unspecific way. But they de facto correlate with the complexity degree of requirements as described on level 6 und 7 of the GQF-LLL, which predominantly address Bachelor and Master degrees and advanced vocational qualifications of level 2 und 3 of the GQF-AVET. It is assumed that this approach promotes both a level-specific description of learning outcomes and professional-scientific competences as well as comparisons and articulation procedures at the interface of VET and academic HE.

Based on the conceptual and empirical analysis further prerequisites for an integrated acquisition of professional-scientific competence could be identified. All forms of problem-oriented learning and assessments promote the acquisition of professionalscientific competences. This requires a didactic which potentially uses all learning formats in a blended or a hybrid manner. It fosters for example problem oriented learning and research-oriented learning which can be interpretated as autonomous and self-reliant actions. Assessment procedures based on case studies, projects and process-based work can test the learner's reflection and judgment of problems and problem solutions. Furthermore they can test the application of complex knowledge e.g. in complex case studies, project work, and process-oriented examinations (HRK, 2013). 


\section{Conclusions and Perspectives}

The prerequisites for the identification of competence-related intersections in the qualification design in both education sectors are given by the capability to act as the common objective as well as by holistic scientific conceptionalisation of competence in the perspective of different pedagogical disciplines, taxonomies, and qualification reference frameworks. Using comparative analytical findings on theoretical concepts on competence and intruments to classify and compare outcomes of learning, the article has discussed intersectional characteristics of professional and scientific competences. As assumed, there is no conceptual dichotomy to design education and training programs per se between the two education sectors. (Markowitsch, 2004; Rein, 2010; 2012). Academic HE programmes are developed along research based disciplinary knowledge and methodology systematics. However it is supposed, that professional and scientific learning outcomes can be designed in a complementary as well as in an integrated or synthesized manner. They could address converging knowledge-intensive and science-related requirements in academic and non-academic environments. The empirical findings about the heterogenous design practice of dual study programmes confirm the relevance of defining systematically the intersection for a professional-scientific compatible design of education programmes to promote the employability in both environments.

Concerning comprehensive requirement areas and competences elucidated in the preceeding chapter, professional-scientific learning outcomes can be described according to a holistic concept of competence and in a level-related manner for a potential and performative mastering of requirements in education, training and at work. Faced with the dominant role of comprehensive qualifications frameworks such as the GQF-LLL for both education sectors, it is further recommended to take into account the descriptors of the competence dimensions and advanced levels found in such frameworks, because they are applicable both for academic and non-academic requirements. Finally, a complementary development and design of the curricula, the didactic and the assessment formats along the principle of constructive alignment is recommended (Arnold \& Lipsmeier, 2006; Schaper, 2012).

The discussed intersectional characteristics potentially provide an orientation for a compatible competence-oriented design and quality development of learning outcomes in education programmes and qualifications within and between both education sectors to solve complex problems and tasks in specific learning or work contexts on the same requirement level.

A number of challenges is given for the development of a sustainable basis for a greater conceptual compatibility of VET and academic HE in terms of a competence-oriented development of learning outcomes and programmes. This calls for corresponding research, testing and development activities. To prepare and safeguard appropriate operationalizations, the discussed intersectional characteristics have to be specified in further $R \& D$ steps focusing on the levels of requirements of the relevant sectors, subjects and disciplines. This can provide a practicable basis for manuals with an eye to quality assurance and quality development of competence-oriented professional-scientific learning outcomes. 
In order to identify commonalities of academic and non-academic requirements, it could make sense to define professional areas such as, for example, information technology or business administration as comprehensive meta-domains. They could be used as starting points for the requirement identification of any prospective programme development in academia, in VET and at the interface of both education sectors. Here subject-matter knowledge could be operationalized as a bridge for requirement identification. But it has to be taken into account that the development of compatible professional-scientific learning outcomes in curricula and assessment will need to be tackled between the poles of the logic and the knowledge generating dynamic of disciplines and the market oriented knowledge requirements of enterprises.

In both the empirically analyzed dual study programmes and in compared short cycle study programmes in the EU and in the US, this challenge has predominantly not been tackled in an integrative-synthesized way. The cumulation of modules which are either subject-discipline oriented or occupation-application oriented had been identified as the preferred programme design way. It can be assumed that a programme design focused on isolated science-oriented modules cumbers addressing professional-scientific requirements in education and training in a compatible sense. This contradicts the integratedholistic qualification concept, thereby generating problems in the didactic backing and curricula fine tuning as well as the conceptual connectivity between qualification (Bailey \& Matsuzuka 2003). One possibility to accomodate a professional-scientific competence orientation and an integrated-holistic programme structure could be a clustering of disciplinary and cross-disciplinary learning units to action areas. This has been implemented in the subject-comprehensive concept of learning fields for German vocational schools (Gerholz \& Sloane, 2008; 2011).

A consistent shift to learning outcomes in the design of qualification programmes which compatibly address complex cognitive and practical requirements in education and training as well as at work and other societal environments implies a resultant usage of relevant key terms like professional and scientific across traditional systemic and institutional contexts. Moreover, it can be assumed that this shift not only makes a holistic capability to act explicit. It also substantially promotes the connectivity and permeability between qualifications within and between VET and academic HE.

\section{References}

Anderson, L. W., \& Krathwohl, D. R. (Eds.). (2001). A taxonomy of learning, teaching and assessing. A revision of Bloom's taxanomy of educational objectives. Boston, MA: Allyn \& Bacon.

Arnold, R., \& Müller, H.-J. (1993). Handlungsorientierung und ganzheitliches Lernen in der Berufsbildung - 10 Annäherungsversuche. Erziehungswissenschaft und Beruf, Vierteljahresschrift für Unterrichtspraxis und Lehrerbildung, 41, H. 4, 323-333.

Arnold, R., \& Lipsmeier, A. (Eds.) (2006). Handbuch der Berufsbildung (2. Ed.). Wiesbaden. 
Bailey, T. R., \& Matsuzuka, Y. (2003). Integration of vocational and academic curricula. Washington, DC: NSF Advanced Technological Education Program.

Biggs, J. (2014). SOLO taxonomy. Structure of observed learning outcomes. Retrieved from http://www.johnbiggs.com.au.

Biggs, J. B., \& Collis, K. F. (1982). Evaluating the quality of learning: the SOLO taxonomy. New York: Academic Press.

Bjornavold, J. (2008). The shift to learning outcomes. Thessalonica.

Bloom, B., Englehart, M., Furst, E., Hill, W., \& Krathwohl, D. (1956). Taxonomy of educational objectives: The classification of educational goals. Handbook I: Cognitive domain. New York, Toronto: Longmans, Green.

Bloom, B., Mesia, B., \& Krathwohl, D. (1964). Taxonomy of educational objectives (Vols. 1-2). New York, NY: David McKay.

Böhle, F. (2010). Handlungskompetenz in Ausbildung und Arbeit - Können hochschulische und berufliche Bildung voneinander lernen? Proceedings of the IG Metall Workshop "Beruflich-betriebliche Bildung - Sind die Handlungs- und Sozialisationsmodelle überholt?", Frankfurt 29. September, 21-30.

Bologna Working Group on Qualifications Frameworks. (2005). A framework of qualifications of the European Higher Education Area, Copenhagen.

Brenner, E., \& Niehs, J. (2008). Curricula Development based on Learning Outcomes An Austrian Case. In E. Cendon, Implementing competence orientation and learning outcomes in Higher Education - Processes and practices in five countries. Krems, 59-81.

Breuer, K. (2005). Berufliche Handlungskompetenz - Aspekte zu einer gültigen Diagnostik in der beruflichen Bildung. bwp@Berufs- und Wirtschaftspädagogik - online, Vol 8. Online: http://www.bwpat.de/ausgabe8/breuer_bwpat8.shtml

Bund-Länderkommission für Bildungsplanung BLK. (2008). Länderübergreifendes Verbundprojekt zur Einbeziehung dualer BA-Studiengänge in das Akkreditierungssystem der Bundesrepublik Deutschland und zur Entwicklung von Strukturvorgaben für duale Studiengänge als Elemente eines nationalen Qualifikationsrahmens (Abschlußbericht), Berlin.

Bundesministerium für Bildung und Forschung (BMBF). (1976). Hochschulrahmengesetz. Bundesgesetzblatt, 185.

Bundesministerium für Bildung und Forschung (BMBF). (2005). Berufsbildungsgesetz. Bundesgesetzblatt, 931.

Bundesministerium für Bildung und Forschung (BMBF). (2006). Förderprogramm Anrechnung beruflicher Kompetenzen auf Hochschulstudiengänge (ANKOM), Bonn.

Bundesministerium für Bildung und Forschung (BMBF). (2011). Förderprogramm Aufstieg durch Bildung: Offene Hochschulen, Bonn.

Bundesministerium für Bildung und Forschung (BMBF), Kultusministerkonferenz, \& Arbeitskreis Deutscher Qualifikationsrahmen. (2011). Deutscher Qualifikationsrahmen für lebenslanges Lernen, Berlin.

Bundesministerium für Bildung und Forschung (BMBF), \& Kultusministerkonferenz. (2014). Bildung in Deutschland 2014, Bonn. 
Bundesministerium für Bildung und Forschung (BMBF). (2014). Eckpunkte zur Struktur und Qualitätssicherung der beruflichen Fortbildung nach Berufsbildungsgesetz (BBiG) und Handwerksordnung (HwO), Bonn.

European Center for the Development of Vocational Training CEDEFOP. (2012). Responding to changing needs: Vocational education and training at tertiary level. Thessalonica.

Chur, D. (2012). Kompetenzorientierung im Studium und der Erwerb von Schlüsselkompetenzen. In B. Kossek, \& C. Zwiauer (Eds.). Universität in Zeiten von Bologna. Zur Theorie und Praxis von Lehr- und Lernkulturen. Wien, 289-316.

Deutscher Bildungsrat. (1970). Empfehlungen der Bildungskommission: Strukturplan für das Bildungswesen, Stuttgart.

Dreyfus, H. L., \& Dreyfus, S. E. (1986). Mind over machine: the power of human intuition and expertise in the age of the computer. Oxford: Basil Blackwell.

Euler, D., \& Severing, E. (2014). Impulspapier für die Diskussion: Durchlässigkeit zwischen beruflicher und akademischer Bildung. Gütersloh: Bertelsmann Stiftung.

European Training Foundation (ETF). (2009). The European Qualifications Framework. Linking to a globalised world. Conference documentation, Brussels, 29-30 January.

European Union EU. (1999). Gemeinsame Erklärung der europäischen Bildungsminister zur Schaffung eines Europäischen Hochschulraumes. Bologna.

European Union (EU). (2002). Declaration of the European Ministers of Vocational Education and Training, and the European Commission, on enhanced European cooperation in vocational education and training. Copenhagen, 29.-30. November.

European Union (EU). (2004). A European Qualifications Framework underpinned by a set of common reference levels, Maastricht.

European Union (EU). (2008). Empfehlung des Europäischen Parlaments und des Rates zur Einrichtung des Europäischen Qualifikationsrahmens für Lebenslanges Lernen, Straßburg.

Fakultäten- und Fachbereichstag Wirtschaftsingenieurwesen e.V. FFBT. (2012). Qualifikationsrahmen Wirtschaftsingenieurwesen, Pforzheim.

Franke, G. (2005). Facetten der Kompetenzbildung. Bielefeld.

Gerholz, K.-H., \& Sloane, P. F. E. (2008). Der Bolognaprozess aus curricularer und hochschuldidaktischer Perspektive Eine Kontrastierung von beruflicher Bildung und Hochschulbildung auf der Bachelor-Stufe. bwp@Berufs- und Wirtschaftspädagogik online, Vol. 14. Online: http://www.bwpat.de/ausgabe14/gerholz_sloane_bwpat14. pdf

Gerholz, K.-H., \& Sloane, P. F. E. (2011). Lernfelder als universitäres Curriculum? Eine hochschuldidaktische Adaption. bwp@Berufs- und Wirtschaftspädagogik online, Vol. 20. Online: http://www.bwpat.de/ausgabe20/gerholz_sloane_bwpat20.pdf

Gonzales, J., \& Wagenaar, R. (2009). Reference points for the design and delivery of degree programmes in Business Tuning. Groningen: Tuning Project.

Harwood, J. (2010). Understanding academic drift: On the institutional dynamics of higher technical and professional education, Minerva, Vol. 48, 4, 413-427. 
Heer, R. (2012). A model of learning objectives. A Taxonomy for learning, teaching, and assessing: A revision of Bloom's taxonomy of educational objectives, Iowa State University.

Hochschulrektorenkonferenz (HRK). (2013). Wissen und Können. Kompetenzziele, Lernergebnisse und Prüfungen studienzentriert formulieren und gestalten, Bonn.

Institut der Deutschen Wirtschaft (IW). (2010). Akademiker - Meist krisenfeste Jobs. Iwd No. 31, 3, Köln.

Jahn, H. (2007). Lehren und Lernen in gestuften Studiengängen - Curriculare Anforderungen und Umsetzungsprobleme. In K. Reiber, \& R. Richter (Eds.). Entwicklungslinien in der Hochschuldidaktik. Ein Blick zurück nach vorn. Berlin, $135-155$.

Kohler, J. (2004). Schlüsselkompetenzen und "Employability" im Bologna-Prozess. In Stifterverband für die Deutsche Wissenschaft (Ed.), Schlüsselkompetenzen und Beschäftigungsfähigkeit. Konzepte für Vermittlung überfachlicher Qualifikationen an Hochschulen. Essen, 5-15.

Kultusministerkonferenz (KMK). (2002, 2009). Anrechnung von außerhalb des Hochschulwesens erworbenen Kenntnissen und Fähigkeiten auf ein Hochschulstudium, Bonn.

Kultusministerkonferenz (KMK). (2003). Ländergemeinsame Strukturvorgaben gemäß $\S 9$ Abs. 2 HRG für die Akkreditierung von Bachelor- und Masterstudiengängen, Bonn.

Kultusministerkonferenz (KMK). (2005, 2017). Qualifikationsrahmen für Deutsche Hochschulabschlüsse, Bonn.

Kultusministerkonferenz (KMK). (2007). Handreichung für die Erarbeitung von Rahmenlehrplänen der Kultusministerkonferenz für den berufsbezogenen Unterricht in der Berufsschule und ihre Abstimmung mit Ausbildungsordnungen des Bundes für anerkannte Ausbildungsberufe, Bonn.

Markowitsch, J. (2004). Die wissenschaftliche Gemeinschaft und Wissenschaftspraxis. In J. Markowitsch (Eds.), Handbuch praxisorientierter Hochschulbildung. Wien, 100-105.

Mertens, D. (1974). Schlüsselqualifikationen - überlegungen zur Identifizierung und Vermittlung im Erst- und Weiterbildungssystem. In G. Faltin (Ed.), Berufsforschung und Hochschuldidaktik - Sondierung des Problems. Hamburg, 204-230.

Nida-Rümelin, J. (2014). Der Akademisierungswahn. Zur Krise beruflicher und akademischer Bildung. Hamburg: Körber Stiftung.

Pletl, R., \& Schindler, G. (2007). Umsetzung des Bologna-Prozesses - Modularisierung, Kompetenzvermittlung, Employability. Das Hochschulwesen, Vol. 55, 35.

Prakopchyk, Y., Blötz, U., Lorig, B., Mettin, G., Milolaza, A., \& Padur, T. (2015). Taxonomie in Fortbildungsqualifikationen, Bonn.

Räbiger, J. (2007). Integration beruflicher und hochschulischer Bildung - die dritte Dimension der Bologna-Reform. In J. Schwarze (Eds.), Arbeitmarkt- und Sozialpolitikforschung im Wandel. Hamburg, 208.

Raffe, D. (2003). Bringing academic education and vocational training closer together. In J. Oelkers (Ed.), Futures of Education 1. Essays from an Interdisciplinary Symposium. Bern, 49-65. 
Rein, V. (2002). Hochschulkompatibilität in der Aufstiegsfortbildung. In: BIBB Dokumentation Fachkongress zu "Neue Konzepte der Berufsbildung in Industrie, Büro und Medienwirtschaft an den Schnittstellen von Aus- und Weiterbildung und Studium" (Forum 7). Bonn, 31-35.

Rein, V. (2010). Deutscher Qualifikationsrahmen - Transformationskatalysator für Berufsund Hochschulbildung. Swiss Political Science Review, Vol. 16.4, 821-825.

Rein, V. (2011). US Associate Degrees - durchlässige Short Cycle Qualifikationen an der Schnittstelle beruflicher und akademischer Bildung. Berufsbildung in Wissenschaft und Praxis. Vol. 4, 49-52.

Rein, V. (2012). Aspekte der Kompatibilität beruflicher und hochschulischer Bildung in der Kompetenzorientierung. bwp@Berufs- und Wirtschaftspädagogik-online, Vol. 23.

Rein, V. (2015). Permeability promoting aspects of the design of qualifications and programmes in terms of competence orientation at the interface of VET and academic HE (DUQUA). Final report (unpublished), Bonn.

Schaper, N. (2012). Zur Kompetenzorientierung in Studium und Lehre. Bonn.

Sitte, W. (2001). Taxonomie. In W. Sitte, \& H. Wohlschlägl, Beiträge zur Didaktik des Geographie- und Wirtschaftskunde Unterrichts. Wien, 473-75.

Sloane, P. F. E., Twardy, M., \& Buschfeld, D. (2004): Einführung in die Wirtschaftspädagogik, Paderborn.

Tuning Project (Ed.). (2006). Eine Einführung in Tuning Educational Structures in Europe. Der Beitrag der Hochschulen zum Bologna-Prozess. Online: http://www.uni deusto.org/tuningeu/images/stories/documents/General_brochure_German_version. pdf

Teichler, U. (2003). Hochschule und Arbeitswelt. Konzeptionen, Diskussionen, Trends. Frankfurt a.M., New York.

Vygotsky, L.S. (1978). Mind and society: The development of higher mental processes. Cambridge, MA: Harvard University Press.

Weinert, F. E. (2001). Vergleichende Leistungsmessung in Schulen - eine umstrittene Selbstverständlichkeit. In F. E. Weinert (Ed.), Leistungsmessungen in Schulen. Stuttgart, Weinheim, Basel, 17-31.

Wildt, J. (1997). Fachübergreifende Schlüsselqualifikationen - Leitmotiv der Studienreform? In U. Welbers (Ed.). Das integrierte Handlungskonzept Studienreform. Neuwied, 198-213.

Wildt, J. (2007). Praxisbezug revisited - Zur hochschuldidaktischen Rekonstruktion von Theorie-Praxis-Verhältnissen in Studium und Lehre. In M. Merkt, \& K. Mayberger (Ed.), Die Qualität akademischer Lehre. Zur Interdependenz von Hochschuldidaktik und Hochschulentwicklung. Innsbruck, 59-72.

Wildt, J. (2011). Kompetenzorientiertes Prüfen. Vortrag auf der Tagung: Lehre im Fokus. Erlangen, 22. July. Online: http://www.fbzhl.de/fileadmin/FBZHL-Upload /Dateien/Wildt_Erlangen_22.07.2011.pdf 
Wolf, H. (2011). Akademiker und Nicht-Akademiker im Wissenskapitalismus. Betriebliche Kooperations- und Interessenskonstellationen. In IG Metall, Dokumentation des IG Metall Workshops "Akademisierung von Betrieben - Facharbeiter/innen ein Auslaufmodell?". Frankfurt, 23-28.

Wolter, A. (2010). Durchlässigkeit zwischen beruflicher Bildung und Hochschule Vom Besonderheitenmythos zur beruflichen Kompetenz. In K. Birkelbach (Eds.), Berufliche Bildung in Zeiten des Wandels. Festschrift für Rolf Dobischat. Baltmannsweiler, 199-219.

Zervakis, P. (2008). Die Problematik der Einführung allgemeingültiger Standards für die Implementierung von Lernergebnissen im Rahmen dezentraler Curriculumsentwicklung. Bonn.

\section{Biographical Notes}

Dr. phil. Volker Rein is an education researcher at the Federal Institute for Vocational Education and Training (BIBB), Department of Professional Learning and Teaching in Bonn, Germany since 2000. He is a specialist in German, European and international program, policy and system developments in Vocational Education and Training (VET) and academic Higher Education (HE). In research and development he has long-term expertise on competence oriented qualification standards and transparency instruments (qualifications frameworks, recognition of prior learning, credit transfer etc.) in Germany, in the EU, the US and at UNESCO. Currently he especially focuses on the connectivity of qualifications in VET and academic qualifications in terms of competence orientation. 